\title{
Enhancement of Hybrid Solar Air Conditioning System using a New Control Strategy
}

\author{
Ahmed Abed Mohammed* \\ Raed Ayad Abduljabbar** \\ ***Department of Mechanical Engineering / University of Technology \\ *Email: 20187@uotechnology.edu.iq \\ **Email: me.21148@uotechnology.edu.iq
}

(Received 14 January 2018; accepted 25 April 2018)

https://doi.org/10.22153/kej.2018.04.002

\begin{abstract}
Enhancement of the performance for hybrid solar air conditioning system was presented in this paper. The refrigerant temperature leaving the condenser was controlled using three-way valve, this valve was installed after the compressor to regulate refrigerant flow rate towards the solar system. A control system using data logger, sensors and computer was proposed to set the opening valve ratio. The function of control program using LabVIEW software is to obtain a minimum refrigerant temperature from the condenser outlet to enhance the overall COP of the unit by increasing the degree of subcooled refrigerant. A variable load electrical heater with coiled pipe was used instead of the solar collector and the storage tank to simulate the solar radiation. Experimental data was measured to study the performance of the system. The proposed system was compared with the conventional one. Results show that the COP of the proposed system was higher than the COP of the conventional system by $10 \%$. In addition, the controlled system saved an electricity of $11.2 \%$. The optimum opening valve ratio fluctuated between 0.3 and 0.4 when the heater power was $500 \mathrm{~W}$.
\end{abstract}

Keywords: Hybrid system, evacuated tubes collector, three-way control valve.

\section{Introduction}

In summer, air conditioning represents a high cost in global building services in both commercial and residential buildings. The increased in thermal loads, living standards and residents comfort demands as well as building architectural characteristics caused an increasing in energy demand for air-conditioning. [1]

Heating, ventilation and air conditioning processes in buildings account about half of energy consumption, specifically air conditioning is expected to contribute significantly to the prospective growth to 2040. [2].

Ha and Vakiloroaya, 2012 [3] estimated the optimum refrigerant temperature entering the condenser in hybrid solar air conditioner system by proposing a by-pass line together with a three-way proportional control valve that installed after the compressor to control the refrigerant flow rate and enhance the performance of the system, results show that the average COP by using the optimal set-point values is higher than the commonly-used design by $6.7 \%$. Also, the lower refrigerant enthalpy entering the evaporator tends to decrease the compressor work and in turn avoids the unnecessary heat rejection in the condenser. Vakiloroaya et al., 2013 [4] developed the hybrid solar air conditioning system by proposing a discharge bypass line together with an inline solenoid valve to increase the subcooling of the refrigerant at partial loads, the solenoid valve installed after the compressor to regulate the mass flow rate of the refrigerant. This development is promising between 25 and $43 \%$ of monthly electricity can be saved on average. Vakiloroaya et al. 2013 [5] derived mathematical models for the components of hybrid solar air conditioner and then validated against experimental results. The models are derived based on the mass and energy 
balance equations merging thermodynamics and heat transfer laws. Simulation results were compared with the experimental data. It was shown that additional heat from solar collector to the refrigerant after the compressor allows it to be switched off longer to consequently reduce the overall electrical energy consumption. Abid and Jassim, 2015 [6] investigated an experimental study of the thermal performance of air conditioning system combined with a solar collector. The prototype consisted of three different process fluid loops: air-conditioning loop, collector loop, and cooling tower loop. The bypass installed after compressor to control the flow rate of the refrigerant and the load on the compressor. Results showed that the COP increased from 2.493 to 2.725 when the solar radiation increased from $572 \mathrm{~W} / \mathrm{m} 2$ to $725 \mathrm{~W} / \mathrm{m} 2$, the average energy saving between $23 \%$ and $32 \%$. Kumar et al., 2016 [7] introduced their study about performance analysis of hybrid solar air conditioning system which consists of $\mathrm{R} 410 \mathrm{a}$ vapour compression refrigeration cycle combined with evacuated tubes collector, the average coefficient of performance was about 2.71 . Hasanen et al., 2017 [8] investigated the mechanical and electrical performance of hybrid solar air conditioning system experimentally and analytically. The performance of hybrid and conventional system were compared. The results showed that the proposed system had not better performance and energy saving than the conventional one.

The aim of this study is to investigate the enhancement of hybrid solar A/C system by utilizing a new strategy of control variable (outlet refrigerant temperature from the condenser) via three-way actuator valve.

\section{Experimental Work}

The test rig consists of seven main components which are: Rotary compressor, air-cooled finned tubes condenser, capillary tube, DX evaporator, electrical heater, three-way control valve. Figures 1,2 and 3 show a schematic block diagram, indoor and outdoor units of the test rig respectively.

The cooling capacity of the compressor is $3.5 \mathrm{~kW}$, and the working fluid is R22. Finned tubes condenser with two rows and 20 tubes per row is used, the length of each row is $75 \mathrm{~cm}$, and the outer tube diameter is $9.57 \mathrm{~mm}$, the input power of condenser fan is $20 \mathrm{~W}$. Direct expansion evaporator with one row and 26 tubes per row is used, the length of the row is $65 \mathrm{~cm}$ and outer tube diameter is $7.6 \mathrm{~mm}$

An electrical heater is used instead of solar collector system to simulate the solar radiation, avoid weather fluctuations and cover a wide range of solar radiation. It is a galvanized steel box with dimensions of $65 \times 25 \times 12 \mathrm{~cm}$, in one side of the box, an electrical coil of $500 \mathrm{~W}$ is supported, and in the other side, copper tube with $12.77 \mathrm{~mm}$ outer diameter and $7 \mathrm{~m}$ length is welded to form a heat exchanger.

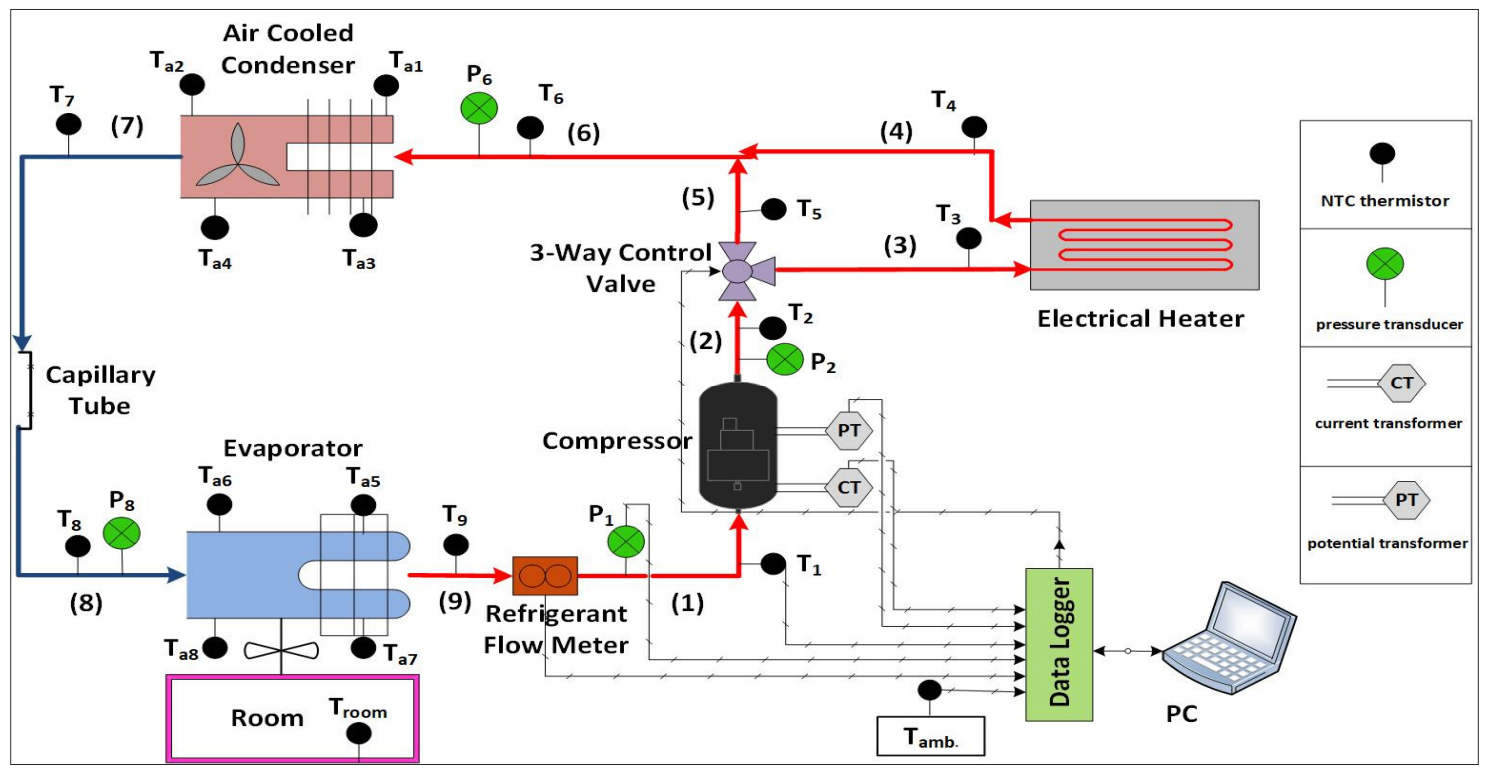

Fig. 1. Schematic diagram of the system. 


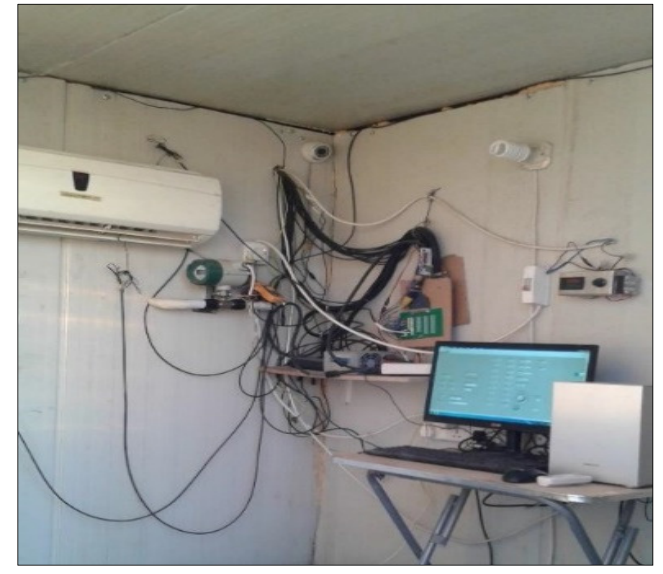

Fig. 2. Indoor unit and control system.

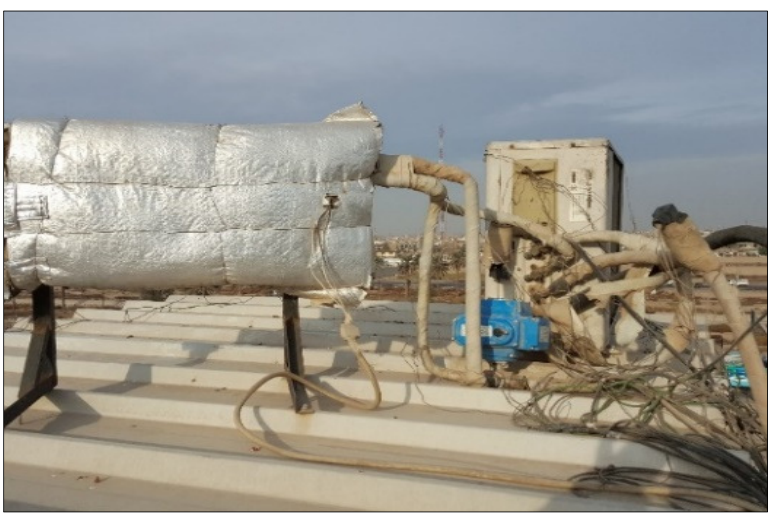

Fig. 3. Outdoor components.

A twisted strip is inserted inside the pipe to increase the heat transfer rate between the refrigerant and pipe wall. The box is insulated from outside with glass wool and aluminum foil. A variac transformer is used to control the output power of the electrical heater manually. Fig. 4 represents the details of the electrical heater.

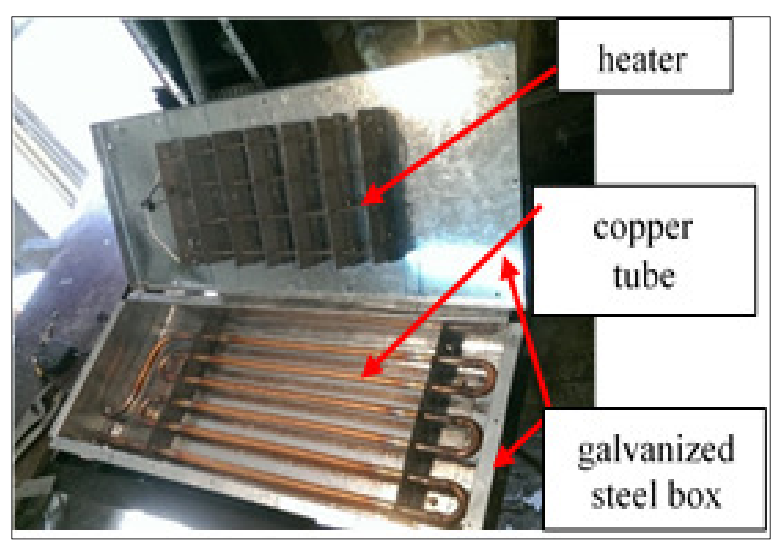

Fig. 4. Details of the electrical heater.
A proportional three-way control valve model (LPA14-403B9CPC3-10-64), T port diverting type is used, with $1 \sim 5 \mathrm{~V}$ control signal actuator. It is installed after the compressor to regulate the flow rate of the refrigerant to the condenser and the electrical heater. The opening ratio of the threeway valve is controlled automatically (according to computer program associated with data acquisition) or manually. Fig. 5 represents the three-way control valve.

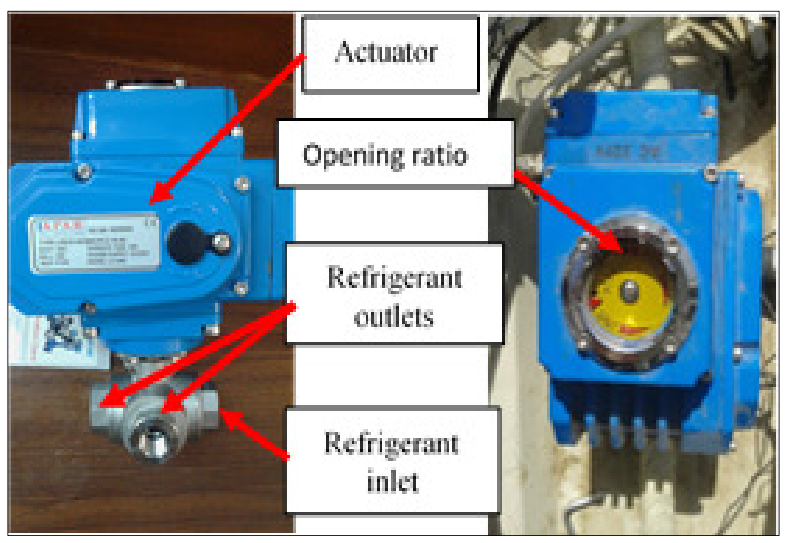

Fig. 5. Three-way control valve.

\section{Test Room}

Fig. 6 represents the test room which is built of sandwich panel room was constructed to represent the conditioning space. The dimensions of the room are $2 \times 2 \times 2 \mathrm{~m}$. The evaporator was installed inside the room, while the compressor, condenser, capillary tube, three-way control valve and electrical heater were installed outside the room. The aim of constructing this room is to control the indoor conditions and reduce the number of variables, so that the effect of the remaining variables can be studied. Two electrical heaters of $1000 \mathrm{~W}$ each was installed inside the room to simulate thermal load and prevent very low temperature that may be stop the system. 


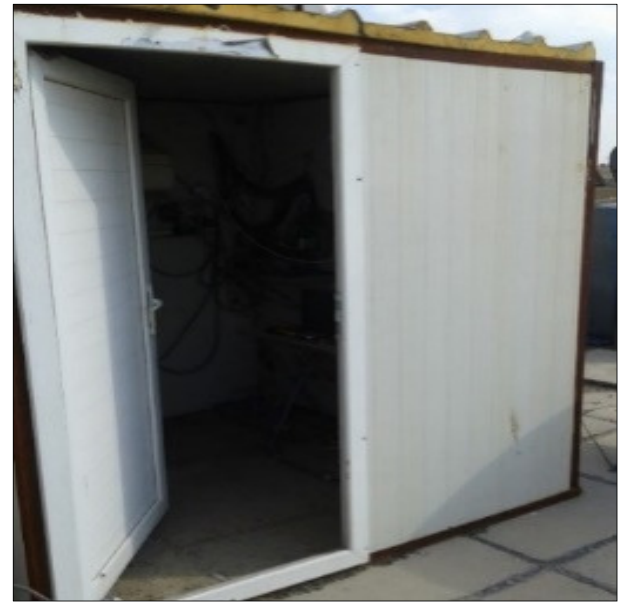

Fig. 6. Test room.

\section{Measuring Instruments}

The parameters data are displayed and recorded automatically as in Table 1.

Negative thermal coefficient thermistor (NTC) is used to measure the temperature. Pressure transducer (Danfoss) is used to measure refrigerant pressure. The gas flow meter is installed at the suction line to measure refrigerant flow rate. Potential transformer (PT) and current transformer (CT) were used to measure the voltage and current of the system respectively. Table 2 represents the measuring instruments and their specifications.

Table 1,

Measuring data.

\begin{tabular}{|c|c|c|}
\hline No. & Parameters & Notation \\
\hline 1 & $\begin{array}{l}\text { Refrigerant temperature before } \\
\text { and after each component. }\end{array}$ & T1- T9 \\
\hline 2 & $\begin{array}{l}\text { Refrigerant pressure before and } \\
\text { after the compressor. }\end{array}$ & $\mathrm{P} 1, \mathrm{P} 2$ \\
\hline 3 & $\begin{array}{l}\text { Refrigerant pressure before } \\
\text { condenser and evaporator. }\end{array}$ & P6, P8 \\
\hline 4 & Refrigerant flow rate. & $\dot{\mathrm{V}}_{\mathrm{r}}$ \\
\hline 5 & $\begin{array}{l}\text { Inlet and outlet air temperature } \\
\text { of the condenser and } \\
\text { evaporator. }\end{array}$ & $\begin{array}{l}\mathrm{T} \text { air evap. in., } \\
\mathrm{T} \text { air evap. out., } \\
\mathrm{T} \text { air cond. in., } \\
\mathrm{T} \text { air cond. out. }\end{array}$ \\
\hline 6 & $\begin{array}{l}\text { Ambient and room } \\
\text { temperature. }\end{array}$ & $\mathrm{T}_{\text {amb., }} \mathrm{T}_{\text {room }}$ \\
\hline 7 & $\begin{array}{l}\text { Voltage and current of the } \\
\text { system. }\end{array}$ & $\mathrm{V}, \mathrm{I}$ \\
\hline 8 & Electrical heater power & $\mathrm{P}_{\text {heater }}$ \\
\hline
\end{tabular}

\section{Control System}

The control system consists of the following:

- Data acquisition (national instrument NI), 32 ports, input power is $11 \sim 30 \mathrm{~V} \mathrm{DC}, 50 \mathrm{~W}$.
- Desktop computer

- Power supply

- Electronic cards and co-axial wire interface.

- Control program with LabVIEW software, the flow chart of the program was shown in Fig. 7. The objectives of the control system are:

1. Record and display the collected data from NTC, pressure transducers, flow meter, current transformer (CT) and potential transformer (PT) to via computer.

2. Control the opening ratio $(\mathrm{R})$ of three - way valve to regulate mass flow rate of the refrigerant that flows across the electrical heater (solar system) or direct to the condenser, by transmitting the signal to the three-way valve actuator according to the input signal transmit from the refrigerant temperature leaving the condenser (T7) via data acquisition.

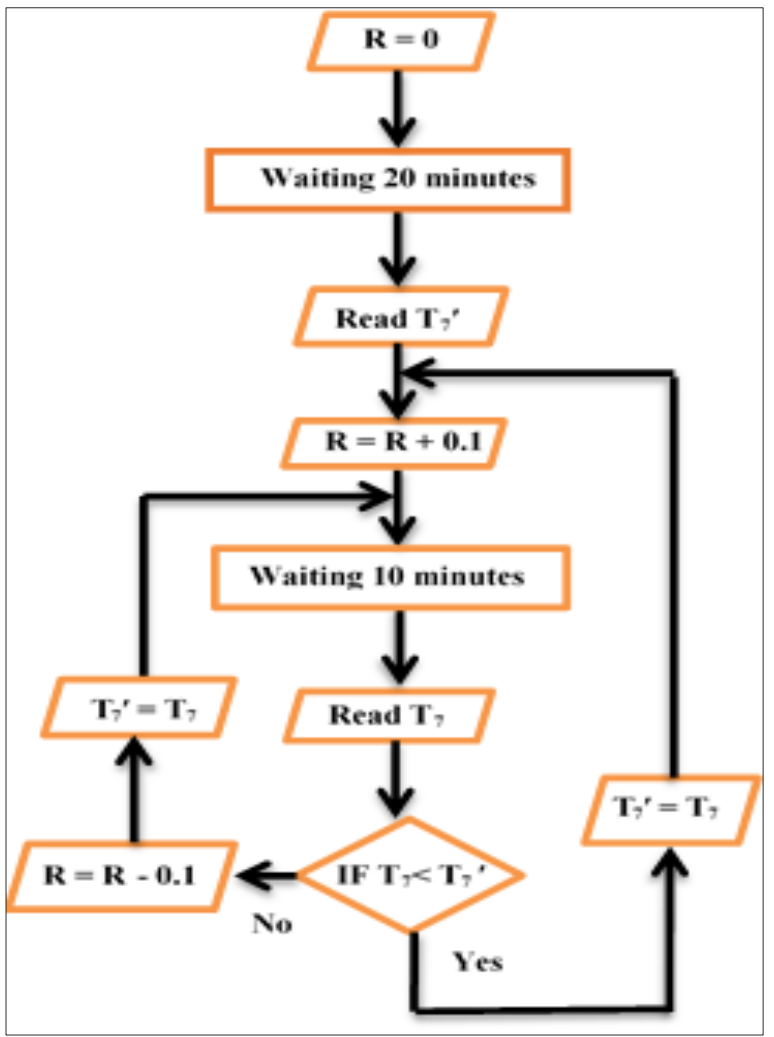

Fig. 7. Flow chart of the control program.

In the automatic mode for the opening valve ratio $(\mathrm{R})$, the control program regulates the ratio of mass flow equation of the refrigerant as a function of refrigerant temperature leaving the condenser (T7), where the opening ratio is set in position to achieve minimum refrigerant temperature leaving the condenser (subcooled) to increase the COP of the system. Fig. 8 represents the national instrument data acquisition. 


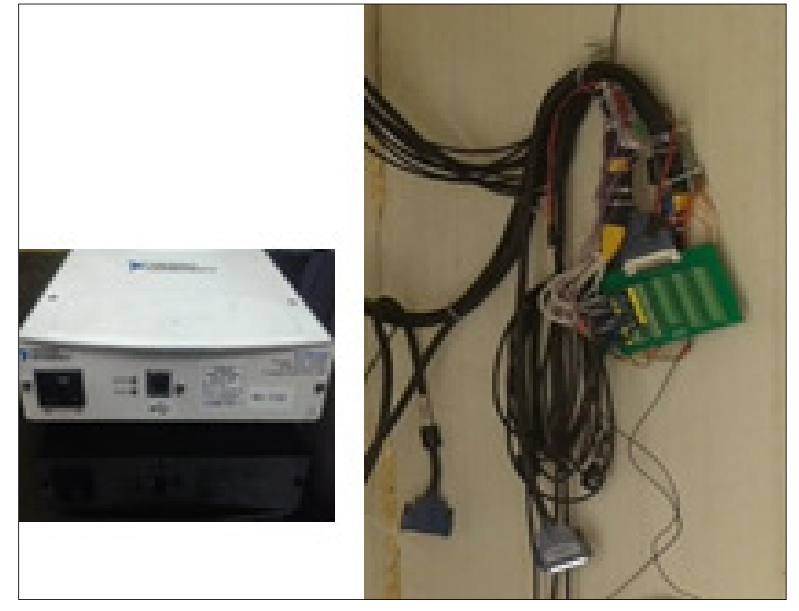

Fig. 8. National instrument data acquisition.

Table 2,

Specifications of measuring instruments.

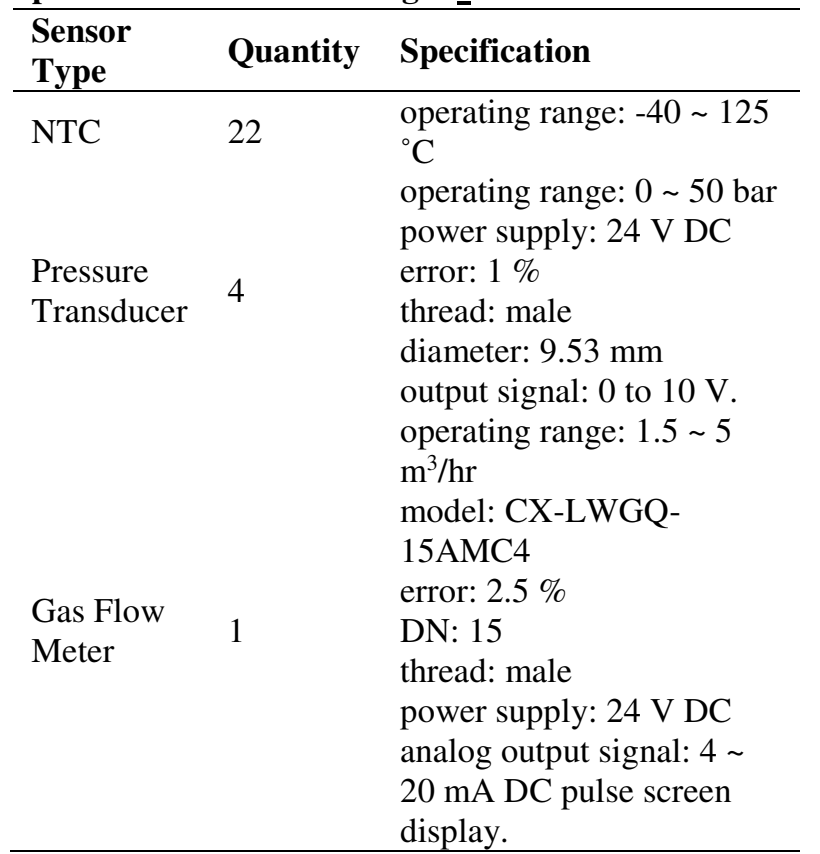

\section{Test Procedures}

All tests were carried out in Baghdad on October 2016. The system was charged with R22. For each test, the following procedures were followed:

- Turn on the system.

- The computer and control program are turned on.

- Set the electrical heater power by the variac manually.

- Set the opening valve ratio, either manually or automatically.

- Set the number of reading and time intervals.
- Record the data (listed in Table 1) in the computer by data logger.

\section{Parameters Calculations}

The power consumption of the system can be calculated by the following equation:

$P_{\text {cons. }}=V \times I$

and the cooling capacity of the evaporator is expressed as:

$Q_{e}=\dot{m}_{r} \times(h 9-h 8)$

while the coefficient of performance of the system is calculated by:

COP $=\frac{Q_{e}}{P_{\text {cons }}}$

\section{Results and Discussions}

Many experimental tests were carried out on the system to study its thermal performance and compare it with the conventional system, just four tests are discussed in this paper as samples to other tests, and each test is studied within four characteristic parameters as following:

\subsection{Refrigerant Temperature}

Fig. 9a, 9b and 9c represent the refrigerant temperature at five positions along time, where the $\mathrm{x}$-axis represents time in minutes and the y-axes represents inlet and outlet temperature of the compressor, outlet temperature of the heat exchanger, inlet and outlet temperature of the condenser and inlet temperature of the evaporator.

Results show that the transition period was taken 20 to 30 minutes until the system reaching the steady state. The refrigerant inlet temperature to the compressor (T1) was about $9.6{ }^{\circ} \mathrm{C}$. The refrigerant temperature leaving the compressor (T2) was approximately constant with time by an average value of $93{ }^{\circ} \mathrm{C}$. The refrigerant temperature leaving the heat exchanger (T4) was directly proportional with the electrical heater power. The refrigerant inlet temperature to the condenser (T6) has the same behavior of $\mathrm{T} 2$, where in the case of automatic opening valve ratio (R), T6 was slightly lower than T2 as shown in Fig. 9a, but in the case of $\mathrm{R}=0.5$ and constant heater power, $\mathrm{T} 6$ was higher than T2 as shown in Fig. 9b. While in the case of $\mathrm{R}=1$ (manually) and variable heater power, $\mathrm{T} 6$ became higher than $\mathrm{T} 2$ when there was a sufficient heater power as shown in Fig. 9c. The refrigerant temperature leaving the condenser (T7) and the refrigerant inlet temperature to the evaporator (T8) 
were approximately constant with time because it depends on $\mathrm{T} 6$ and ambient temperature, and their values do not have a big change with time. The average values of $\mathrm{T} 7$ and $\mathrm{T} 8$ were $41.3{ }^{\circ} \mathrm{C}$ and 6.1 ${ }^{\circ} \mathrm{C}$ respectively.

\subsection{Air Temperature}

Fig. 10a, 10b and 10c represent air temperature with time, where the $\mathrm{x}$-axis represents time recorded and the y-axis represents the inlet and outlet air temperature of the condenser and evaporator, room and ambient temperature.

The air temperature inlet the condenser has approximately the same value of the ambient temperature and it can be identical. The average air temperature difference between inlet and outlet the condenser was about $8.3{ }^{\circ} \mathrm{C}$. The air temperature inlet the evaporator has the same behavior of the room temperature and it can be identical. It is clear that there is some fluctuation in the room temperature, and this is because of fluctuation in the thermal load inside the room. The average air temperature difference between inlet and outlet the evaporator was about $14.4{ }^{\circ} \mathrm{C}$.

\subsection{Refrigerant Pressure and Flow Rate}

The representation of the refrigerant pressure $(\mathrm{P} 1, \mathrm{P} 2, \mathrm{P} 6$, and $\mathrm{P} 8)$ and volumetric flow rate with time were shown in Fig. 11a, 11b and 11c.

The refrigerant pressure follows the ambient temperature, it increased with time as shown in Fig. 11a, while it approximately constant with time as shown in Fig. 11b and 11c. The refrigerant pressure leaving the compressor (P2) was slightly higher than the refrigerant pressure inlet the condenser (P6) in the controlled and uncontrolled hybrid solar air conditioning system. The average value of the volumetric flow rate was slightly decreased with time as shown in Fig. 11a, it ranged between 3.12 and $3.58 \mathrm{~m}^{3} / \mathrm{hr}$, while it seemed constant with time by average value of $3.29 \mathrm{~m}^{3} / \mathrm{hr}$ as shown in Fig. $11 \mathrm{~b}$ and $11 \mathrm{c}$.

\subsection{Power Consumption, Cooling Capacity, Electrical Heater Power, Opening Valve Ratio and Coefficient of Performance}

The representation of power consumption $\left(\mathrm{P}_{\text {cons. }}\right)$, evaporator cooling capacity $\left(\mathrm{Q}_{\mathrm{e}}\right)$, electrical heater power $\left(\mathrm{P}_{\text {heater }}\right)$, opening valve ratio $(\mathrm{R})$ and coefficient of performance (COP) are depicted in Fig. 12a, 12b and 12c.
The power consumption is slightly increased with time as the thermal load increased, its average values are 977, 1116 and $1082 \mathrm{~W}$. Thus, the controlled system consumes less electrical power than another. $Q_{e}$ is fluctuated with time because of the fluctuation in the thermal load inside the room, this lead to oscillate the COP of the system. $\mathrm{Q}_{\mathrm{e}}$ is about $2985 \mathrm{~W}$. The average value of the COP is 3 as shown in Fig 12a. While it equals to 2.7 as shown in Fig. 12b and 12c. It noted that COP of the controlled system is higher than COP of the uncontrolled one.

In the case of controlled system, the refrigerant temperature leaving the condenser (T7) ranged from 36.6 to $43.4^{\circ} \mathrm{C}$ when the heater power ranged from 0 to $500 \mathrm{~W}$ as shown in Fig. 9a and 12a. While in the case of uncontrolled system, the refrigerant temperature leaving the condenser (T7) ranged from 40 to $43.8{ }^{\circ} \mathrm{C}$ when the heater power ranged from 0 to $250 \mathrm{~W}$ as shown in Fig. 9c and 12c. That is mean, the controller can achieve lowest T7 during increase the solar radiation.

The controller plays an important role in enhancement the performance of hybrid solar air conditioning system, where it achieved minimum possible refrigerant temperature leaving the condenser (T7) with maximum possible solar radiation. The lowest $\mathrm{T} 7$ means higher degree of subcooled and hence higher refrigeration effect. Also, higher solar radiation lead to lower power consumption of the system.

The opening valve ratio ( $R$ ) increased by increasing the heater power (solar radiation) and fluctuated between 0.3 and 0.4 when the heater power is $500 \mathrm{~W}$ as shown in Fig. 12a. So, this ratio represents the optimum ratio which achieves maximum value of $\mathrm{COP}$ at certain conditions.

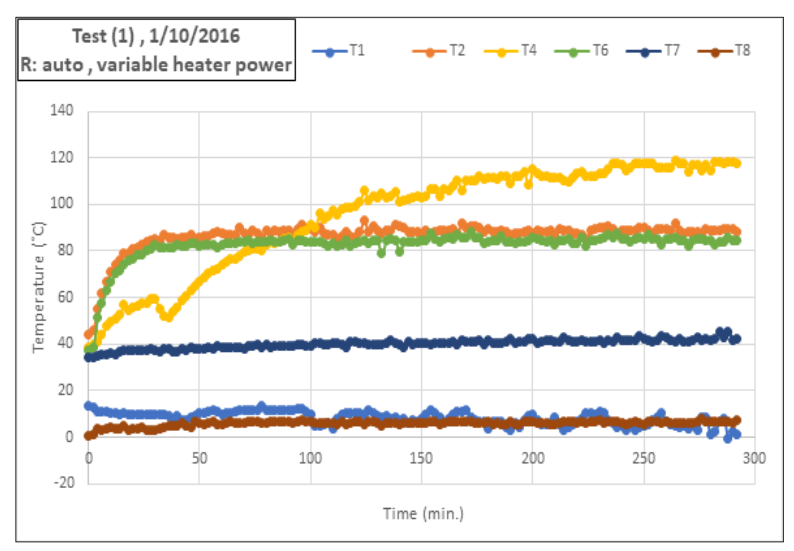

Fig. 9a. Refrigerant temperature with time for test 1 


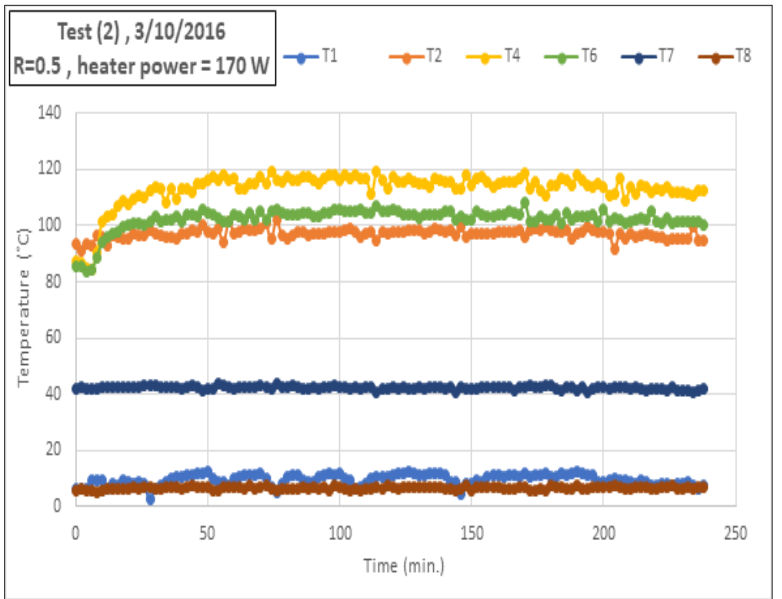

Fig. 9b. Refrigerant temperature with time for test2.

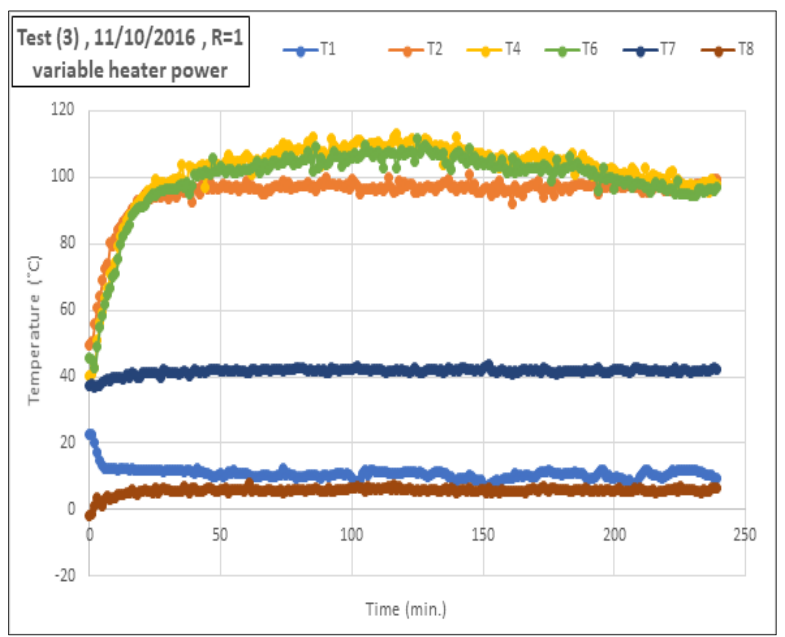

Fig. 9c. Refrigerant temperature with time for test3.

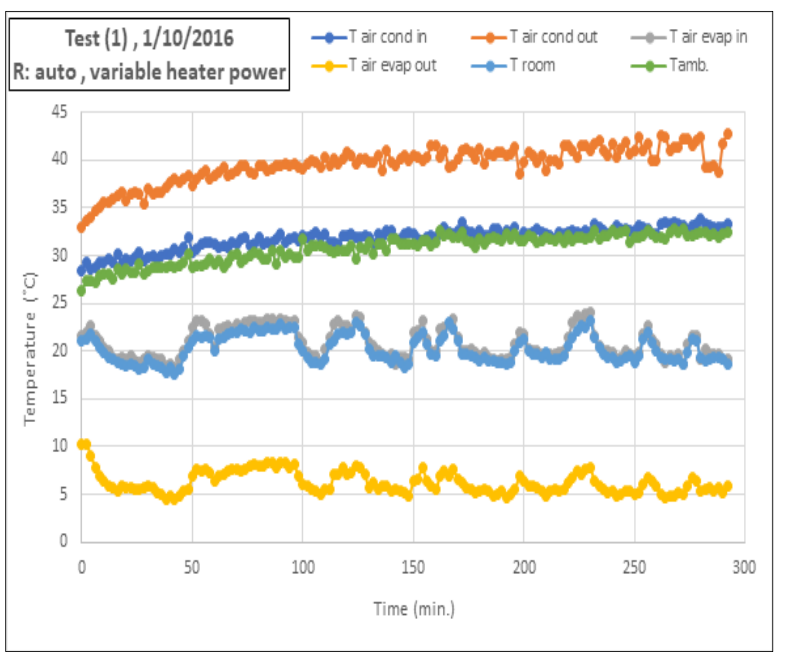

Fig. 10a. Air temperature with time for test 1.

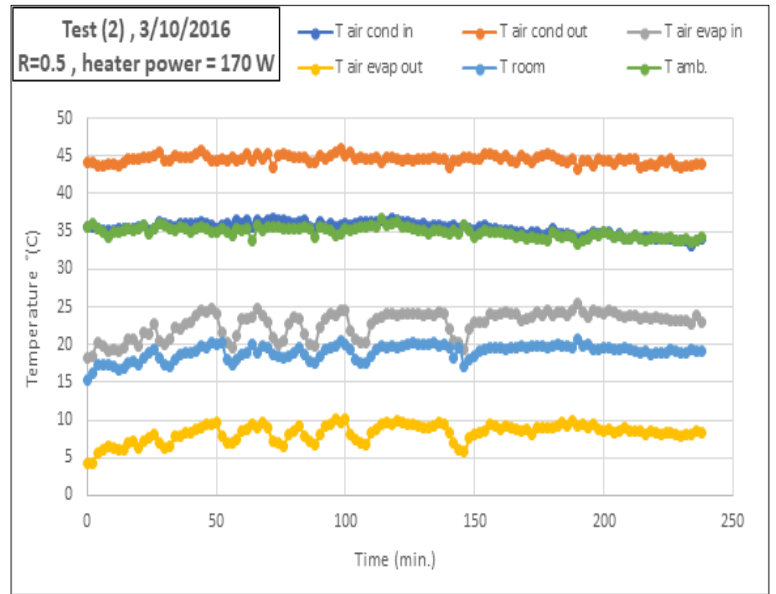

Fig. 10b. Air temperature with time for test 2.

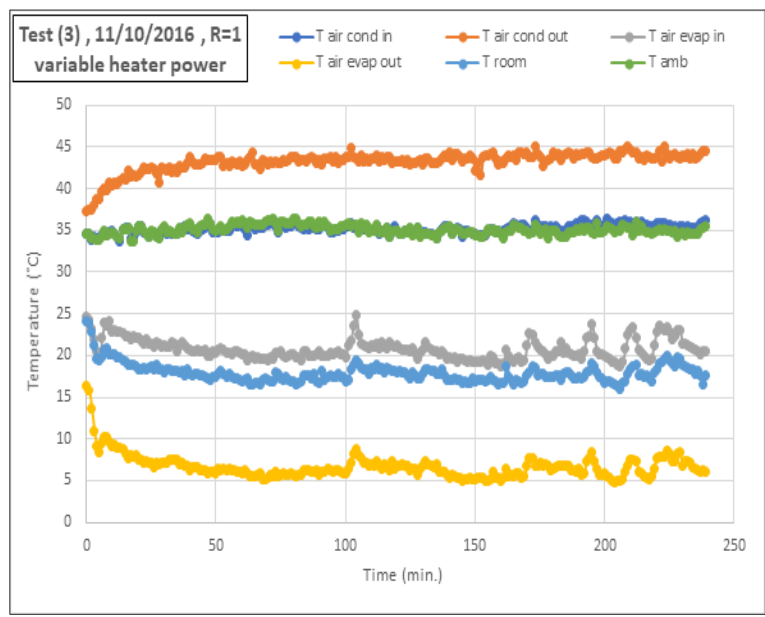

Fig. 10c. Air temperature with time for test 3.

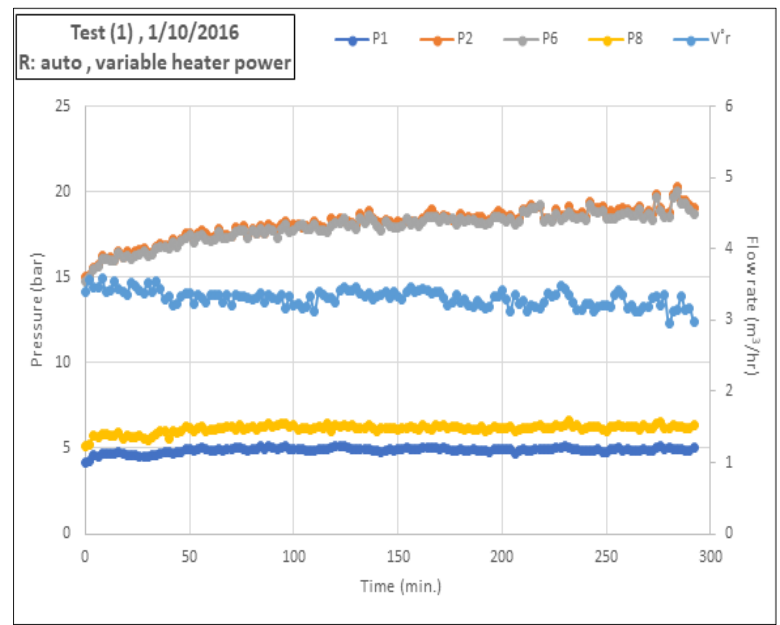

Fig. 11a. Refrigerant pressure and volumetric flow rate with time for test 1 . 


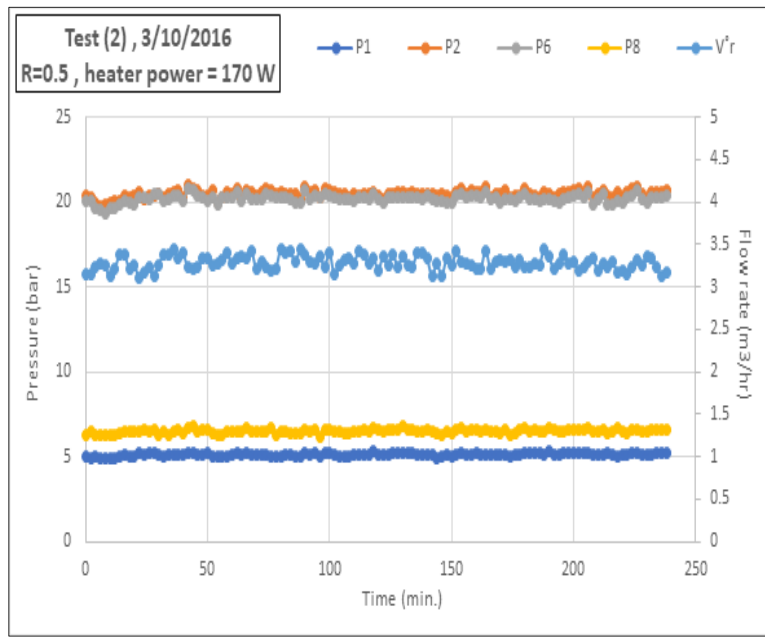

Fig. 11b. Refrigerant pressure and volumetric flow rate with time for test 2 .

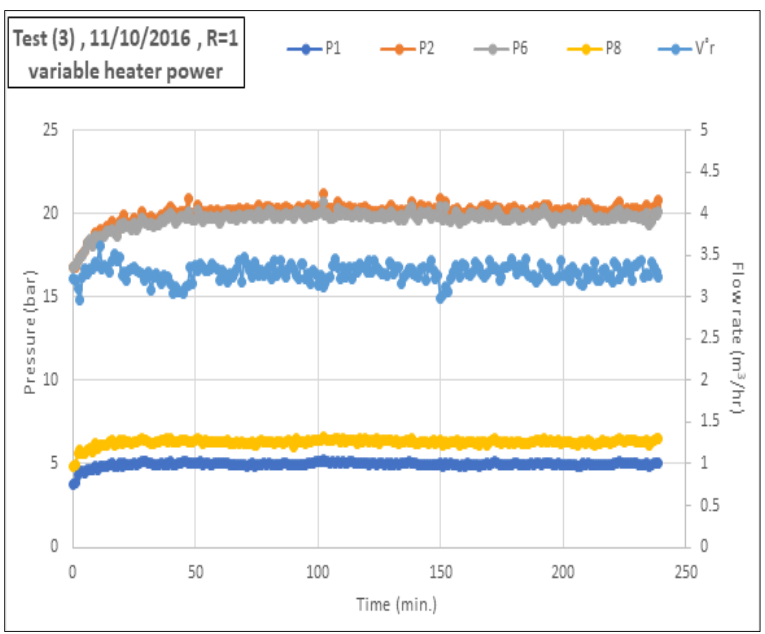

Fig. 11c. Refrigerant pressure and volumetric flow rate with time for test 3 .

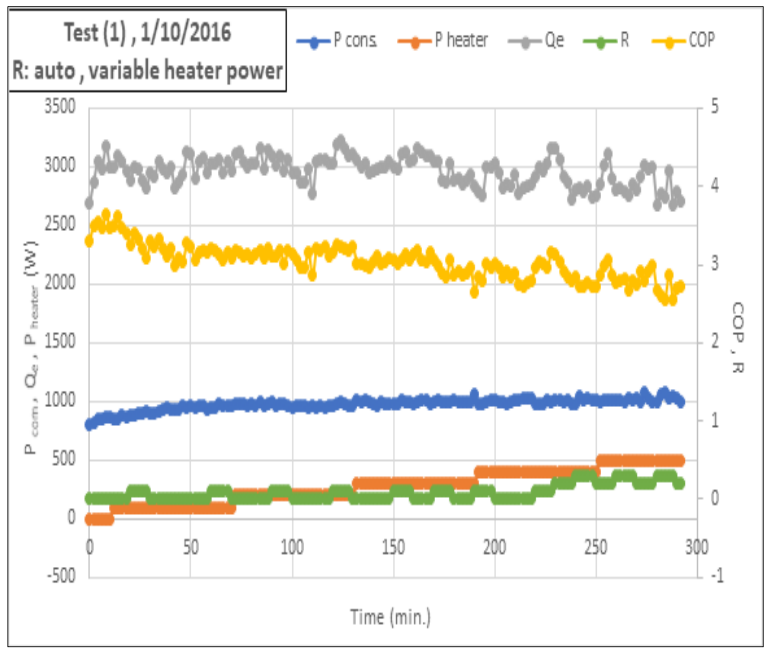

Fig. 12a. Power consumption, cooling capacity, electrical heater power, opening valve ratio and coefficient of performance with time for test 1 .

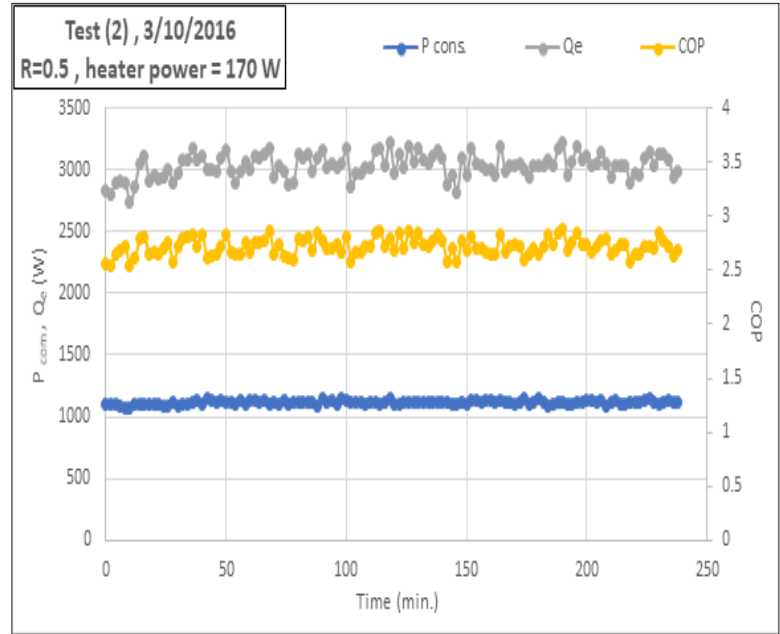

Fig. 12b. Power consumption, cooling capacity and coefficient of performance with time for test 2 .

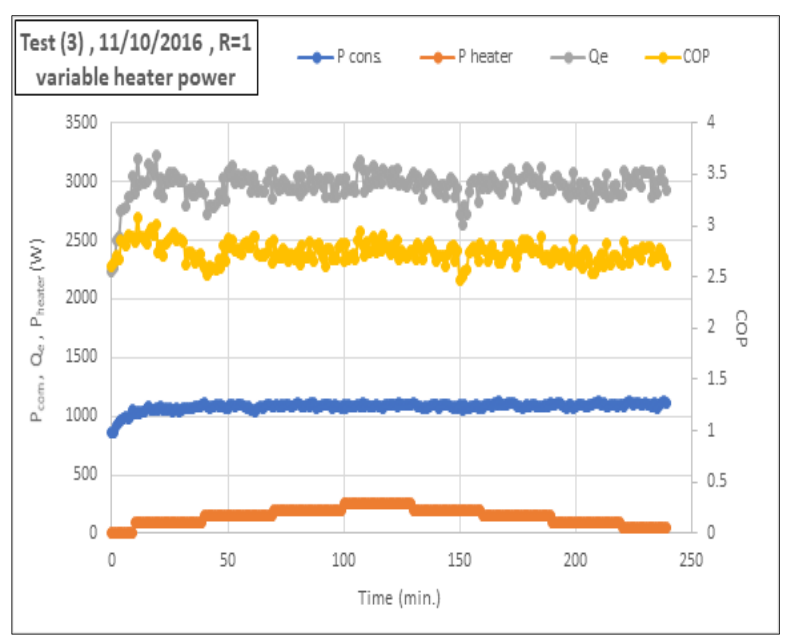

Fig. 12c. Power consumption, cooling capacity, electrical heater power and coefficient of performance with time for test 3 .

\section{Conclusions}

1. Ability of utilizing three-way valve system in the improving the performance of hybrid solar air conditioning system.

2. This type of controller gives a wide scope to prepare alternative programmable software to regulate system performance by controlling other variables (pressure, enthalpy, etc.) to improve system efficiency.

3. The COP of the controlled hybrid solar air conditioning system is higher than the COP of the uncontrolled one by $10 \%$.

4. The controlled system saved an electrical power of $11.2 \%$. 
5. The optimum opening valve ratio which achieves maximum value of $\mathrm{COP}$ at certain conditions is ranged between 0.3 and 0.4 .

6. Possibility of modeling the system using the electrical heater with variable capacity instead of the solar collector and the storage tank.

\section{Nomenclature}

\begin{tabular}{|c|c|}
\hline $\begin{array}{l}\mathrm{COP} \\
\mathrm{h} 8\end{array}$ & $\begin{array}{l}\text { coefficient of performance. } \\
\text { refrigerant enthalpy inlet the } \\
\text { evaporator. }\end{array}$ \\
\hline h9 & $\begin{array}{l}\text { refrigerant enthalpy outlet the } \\
\text { evaporator. }\end{array}$ \\
\hline & $\begin{array}{l}\text { current passes through the } \\
\text { system. }\end{array}$ \\
\hline & erant mass flow rate. \\
\hline 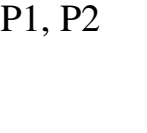 & $\begin{array}{l}\text { refrigerant pressure inlet and } \\
\text { outlet of the compressor } \\
\text { respectively. }\end{array}$ \\
\hline 6 & $\begin{array}{l}\text { refrigerant pressure inlet to } \\
\text { condenser. }\end{array}$ \\
\hline 8 & $\begin{array}{l}\text { refrigerant pressure inlet to } \\
\text { evaporator. }\end{array}$ \\
\hline cons & $\begin{array}{l}\text { power consumption by the } \\
\text { system }\end{array}$ \\
\hline $\mathrm{Q}_{\mathrm{e}}$ & $\begin{array}{l}\text { cooling capacity of the } \\
\text { evaporator. }\end{array}$ \\
\hline & $\begin{array}{l}\text { ratio of the opening valve to the } \\
\text { storage tank to the opening } \\
\text { valve to condenser directly. }\end{array}$ \\
\hline , T2 & $\begin{array}{l}\text { refrigerant temperature inlet and } \\
\text { outlet of the compressor } \\
\text { respectively. }\end{array}$ \\
\hline$\Gamma 3, \mathrm{~T} 4$ & $\begin{array}{l}\text { refrigerant temperature inlet and } \\
\text { outlet of the storage tank } \\
\text { respectively. }\end{array}$ \\
\hline 5 & $\begin{array}{l}\text { refrigerant temperature in the } \\
\text { bypass line. }\end{array}$ \\
\hline Г6, T7 & $\begin{array}{l}\text { refrigerant temperature inlet and } \\
\text { outlet of the condenser } \\
\text { respectively. }\end{array}$ \\
\hline$\Gamma 8, \mathrm{~T} 9$ & $\begin{array}{l}\text { refrigerant temperature inlet and } \\
\text { outlet of the evaporator } \\
\text { respectively. }\end{array}$ \\
\hline ir evap. in & $\begin{array}{l}\text { air temperature inlet to the } \\
\text { evaporator. }\end{array}$ \\
\hline $\begin{array}{l}\mathrm{T}_{\text {air evap. }} \\
\text { out }\end{array}$ & $\begin{array}{l}\text { air temperature outlet from the } \\
\text { evaporator. }\end{array}$ \\
\hline . & $\begin{array}{l}\text { air temperature inlet to the } \\
\text { condenser. }\end{array}$ \\
\hline & $\begin{array}{l}\text { air temperature outlet from the } \\
\text { condenser. }\end{array}$ \\
\hline & ambient dry bulb temperature. \\
\hline
\end{tabular}

$\begin{array}{lll}\mathrm{V} & \begin{array}{l}\text { voltage passes through the } \\ \text { system. }\end{array} \\ \dot{\mathrm{V}}_{\mathrm{r}} \quad \begin{array}{l}\text { volumetric flow rate of } \\ \text { refrigerant in the suction line. }\end{array} & \mathrm{m}^{3} / \mathrm{hr}\end{array}$

\section{References}

[1] H.M. Henning, Solar assisted air conditioning of buildings - an overview, Applied Thermal Engineering 27 (2006) 1734-1749.

[2] M.T. Evans, N. Kapur, J. Summers, H. Thompson, D. Oldham, an experimental and theoretical investigation of the extent of bypass air within data centres employing aisle containment, and its impact on power consumption, Applied Energy 186 (2016) 457-469.

[3] Q.P. Ha, V. Vakiloroaya, a novel solarassisted air-conditioner system for energy savings with performance enhancement, Procardia Engineering 49 (2012) 116-123.

[4] V. Vakiloroaya, R. Ismail, Q.P. Ha, Development of a new energy-efficient hybrid solar-assisted air conditioning system, International Symposium on Automation and Robotics in Construction and Mining 30 (2013) 1424-1435.

[5] V. Vakiloroaya, Q.P. Ha, M. Skibniewski, Modeling and experimental validation of a solar-assisted direct expansion air conditioning system, Energy and Buildings 66 (2013) 524-536

[6] M.A. Abid, N.A. Jassim, Experimental evaluation of thermal performance of solar assisted air conditioning system under Iraq climate, Journal of Energy Technologies and Policy 5 (2015) 1-13.

[7] S. Kumar, D. Buddhi, H.K. Singh, Performance analysis of solar hybrid airconditioning system with different operating conditions, Imperial Journal of Interdisciplinary Research 2 (2016) 19511956.

[8] H.M. Hussain, L.J. Habeeb, O.J. Abbas, Investigation on solar hybrid cooling system with high latent cooling load, Advances in Environmental Biology 11 (2017) 24-36. 


\section{تحسين الاداء لنظام التبريا الشمسي الهجين باستخدام ستراتيجية سيطرة جليدة \\ رائد اياد عبد الجبار \\ أحمد عبد محمد*

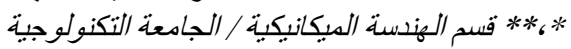

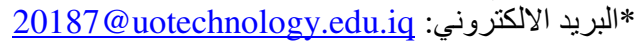 \\ me.21148@uotechnology.edu.iq البريد الالكتروني:**** الانكي:}

في هذا البحث تم در اسة تحسين الاداء لنظام التبريد الثمسي الهجين ، حيث تم نصب صمام تحكم ثلاثي بعد الضاغط مباشرة لغرض التحكم التحم في درجة

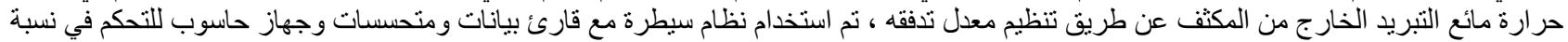

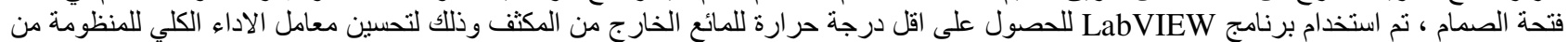

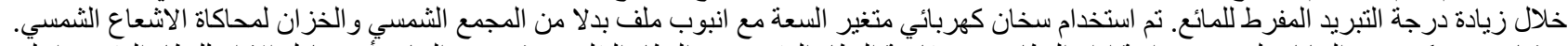

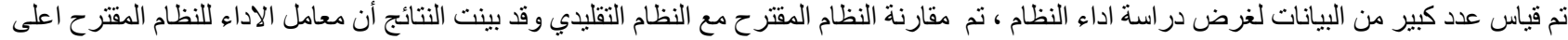

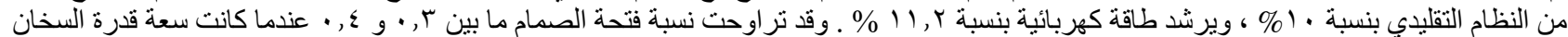
حوالي ... 